\title{
Assessment of West Virginia public healthcare professionals' knowledge, attitudes and behaviors regarding of the oral implications of HPV following an educational presentation
}

\author{
Renee Cooper-Frantz
}

Follow this and additional works at: https://researchrepository.wvu.edu/etd

\section{Recommended Citation}

Cooper-Frantz, Renee, "Assessment of West Virginia public healthcare professionals' knowledge, attitudes and behaviors regarding of the oral implications of HPV following an educational presentation" (2014). Graduate Theses, Dissertations, and Problem Reports. 5395.

https://researchrepository.wvu.edu/etd/5395

This Thesis is protected by copyright and/or related rights. It has been brought to you by the The Research Repository @ WVU with permission from the rights-holder(s). You are free to use this Thesis in any way that is permitted by the copyright and related rights legislation that applies to your use. For other uses you must obtain permission from the rights-holder(s) directly, unless additional rights are indicated by a Creative Commons license in the record and/ or on the work itself. This Thesis has been accepted for inclusion in WVU Graduate Theses, Dissertations, and Problem Reports collection by an authorized administrator of The Research Repository @ WVU. For more information, please contact researchrepository@mail.wvu.edu. 
Assessment of West Virginia public healthcare professionals' knowledge, attitudes and behaviors regarding of the oral implications of HPV following an educational presentation.

\section{Renee Cooper-Frantz, BSDH}

Thesis Submitted to the

School of Dentistry

West Virginia University

in partial fulfillment of the requirements for the degree of

Masters of Science in

Dental Hygiene

Dr. Christina DeBiase BSDH, MS, EdD, chair

Alcinda K Trickett-Shockey, BSDH MA DHSc

Amy Funk, MSDH

Department of Dental Hygiene

\section{Morgantown, West Virginia}

2014

Keywords: knowledge, attitudes and behaviors, human papillomavirus, oral cancer, continuing education

Copyright 2014 Renee Cooper-Frantz 


\begin{abstract}
Assessment of West Virginia public health professionals' knowledge, attitudes and behaviors regarding of the oral implications of HPV following an educational presentation.

Renee Cooper-Frantz
\end{abstract}

Human Papillomavirus (HPV), the most common sexually transmitted infection in the United States, was firmly linked to a new subset of oropharyngeal squamous cell carcinomas (OSCC's) in late 2007. With growing rates of West Virginians affected by HPV-related oral cancers it becomes pertinent to verify that public healthcare professionals of all disciplines are aware of this causal relationship and educating their patients. The purpose of this study was to determine the knowledge level, attitudes and behaviors of a convenience sample of West Virginia's public healthcare professionals regarding the oral implications of HPV before and after and educational presentation. A pre- and post- intervention survey methodology was utilized with an additional survey mailed to the sample population four months later. Chi-square tests for independence and binary logistic regression were utilized to determine any significant differences of answer choice on all three surveys. Statistical analysis revealed a significant increase in knowledge concerning oral cancer related to HPV on two of the three survey questions $(\mathrm{X} 2=6.4, \mathrm{p}=0.03, \mathrm{X} 2=6.3, \mathrm{p}=0.02)$. After the educational lecture participants indicated they were more likely to engage and educate the public about oral cancer caused by HPV (X2= 4.2, $\mathrm{p}=0.08)$, encourage their at-risk patients to seek oral cancer screenings $(\mathrm{X} 2=2.1, \mathrm{p}=0.18)$ and claim to have taken every opportunity to speak with patients about oral cancer caused by HPV (X2=14.5, p=0.0001). Knowledge of and patient education efforts by West Virginia public healthcare providers concerning the oral implications of HPV has increased as a result of the lecture. The knowledge gain indicated knowledge deficiencies on the topic which indicates the topics' future application for interprofessional education (IPE). It is recommended that this topic be applied to IPE in other states or within other settings such as the correctional environment or Native American reservations. 


\section{Table of Contents}

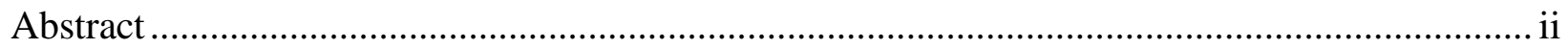

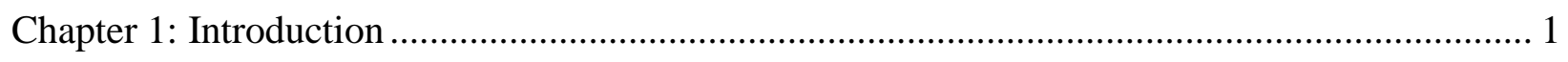

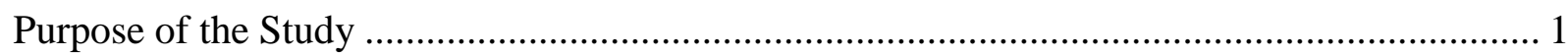

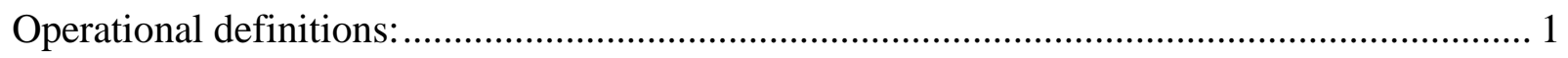

Research Questions ............................................................................................... 1

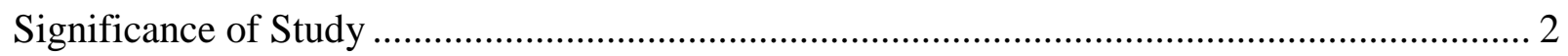

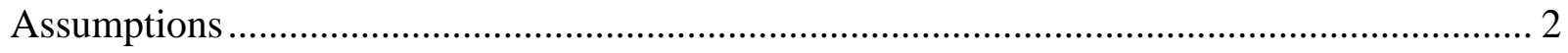

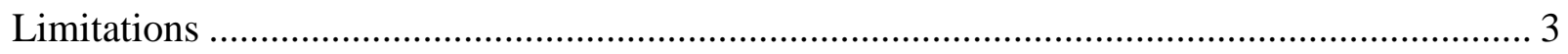

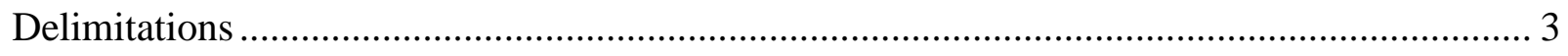

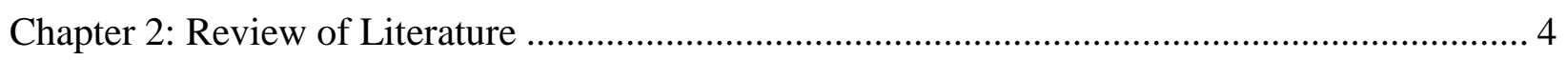

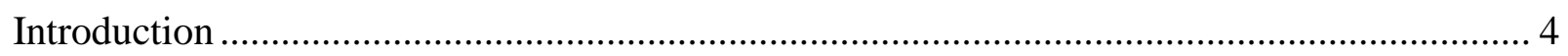

Historic Perspectives of HPV ....................................................................................... 4

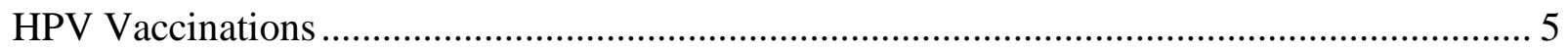

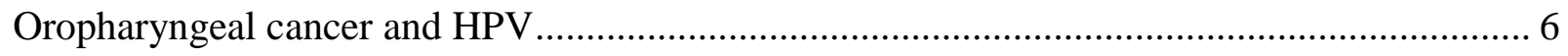

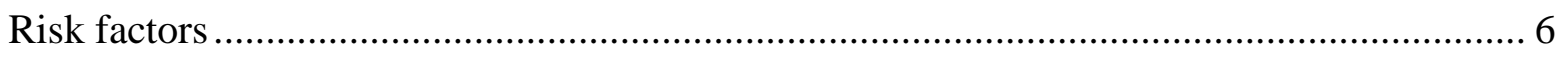

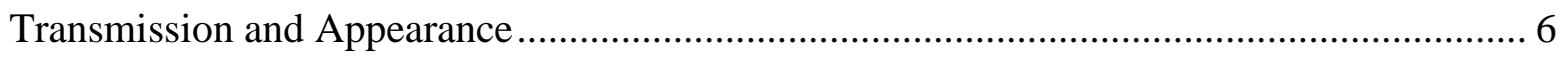

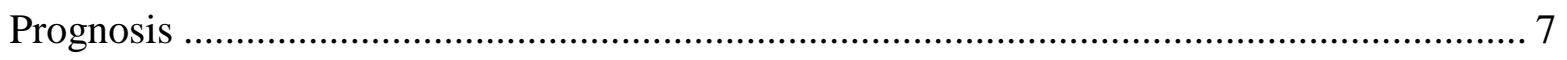

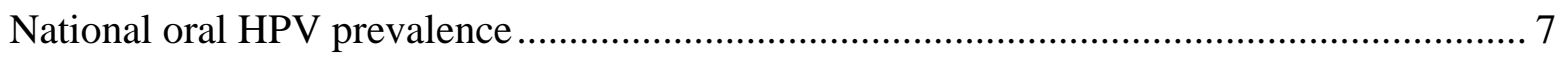

Oral HPV prevalence in West Virginia ................................................................ 7

Early Detection of HPV-associated oropharyngeal cancer .......................................... 7

Behavior Change Models and Interprofessional Education .......................................... 9

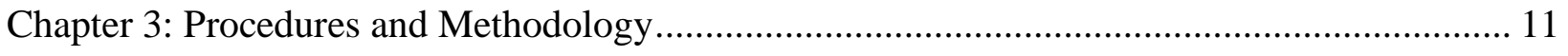

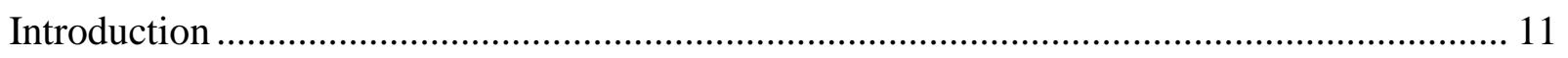




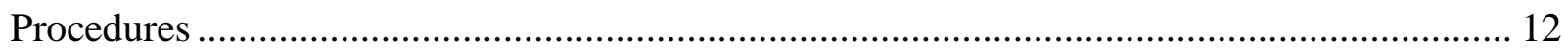

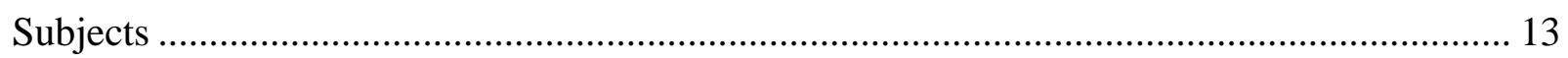

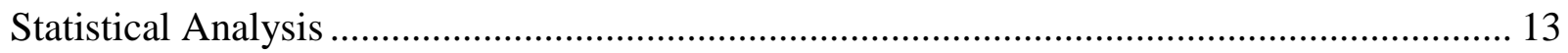

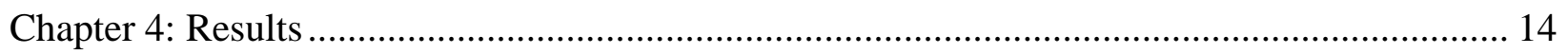

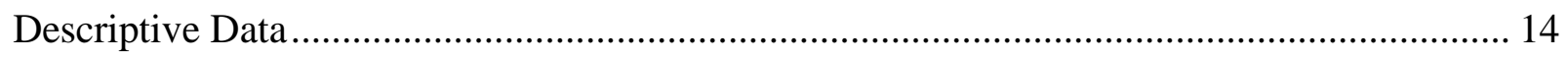

Chi Square test for Independence ......................................................................... 16

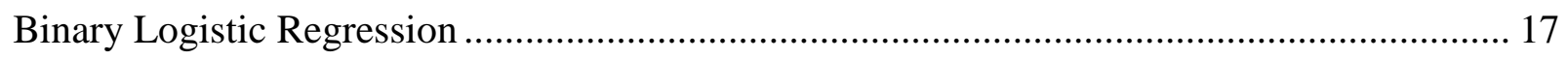

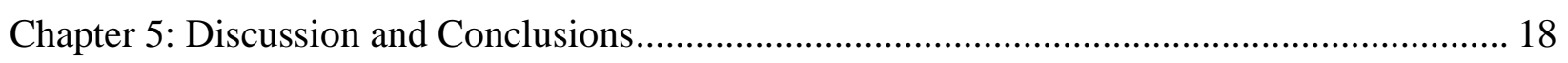

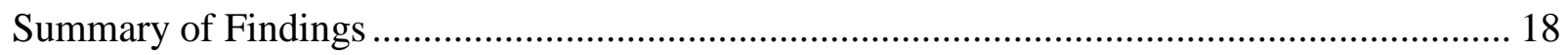

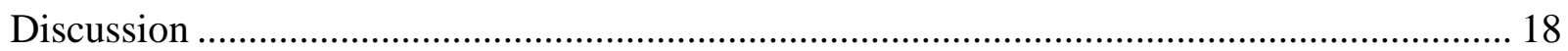

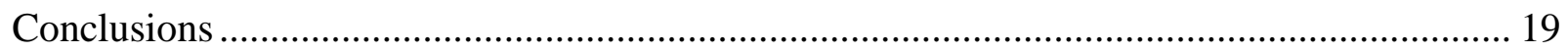

Recommendations for Further Research ................................................................. 20

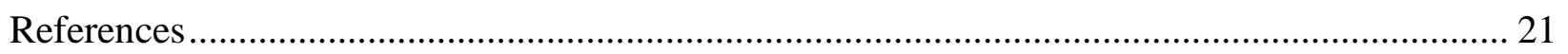

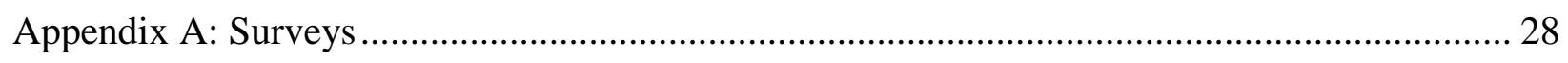

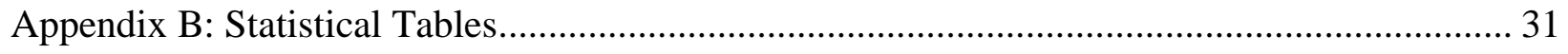




\section{Chapter 1: Introduction}

\section{Purpose of the Study}

The purpose of this study was to determine the knowledge level, attitudes and behaviors of a convenience sample of West Virginia's public healthcare professionals regarding the oral implications of HPV before and after and educational presentation.

\section{Operational definitions:}

Interprofessional education (IPE): When students from two or more professions learn about, from and with each other to enable effective collaboration and improve health outcomes (WHO, 2010).

Continuing interprofessional education (CIPE): Formal postlicensure interprofessional education. Oropharyngeal squamous cell carcimoma (OSCC): Carcinoma of the squamous cells associated with the oropharynx (i.e. anatomical structures include the palatine tonsils, the base of the tongue, and the area between the palatine tonsils and the larynx).

Public healthcare professionals: medical and dental professionals involved in direct patient care at a public health department within the state of West Virginia.

\section{Research Questions}

- Are public health professionals, employed by the West Virginia State Department of Health (n 370) aware of information concerning the relationship between oropharyngeal cancers and HPV?

- Are they aware of available HPV-specific oral cancer detection strategies?

- Are the patients they see at-risk for developing oral cancer related to HPV?

- In their opinion, are they educating their patients about this infectious relationship? 


\section{Significance of Study}

At the time of this project, no other research has been conducted on this subject with this sample population. To date, information concerning the knowledge, attitudes or behaviors of public health professionals is unknown. To ensure adequate education of public health professionals, it is necessary to discern their current level of knowledge to fine tune future educational initiatives, specifically IPE.

Human Papillomavirus (HPV), the most common sexually transmitted infection in the United States, was found to be directly related to a new subset of oropharyngeal squamous cell carcinomas (OSCC's) in late 2007 (Centers for Disease Control and Prevention (CDC), 2014; D'Souza et al., 2007). There were 1,263 oropharyngeal cancers in West Virginia from 2005 to 2009, 903 of which were males (West Virginia Department of Health and Human Resources (WV DHHR), 2012). HPV-associated oropharyngeal cancer rates in West Virginia from 20062010 for females were 1.60-1.93 (per 100,000) and for males were 6.09-7.03 (per 100,000) (CDC, 2014).

Since West Virginians exceed the national rate for persons affected by oral cancers related to HPV, it becomes pertinent to verify that public healthcare professionals of all disciplines are aware of its relationship. IPE is suggested as a means to share information that concerns multiple disciplines with the common goal of improving patient safety and welfare.

\section{Assumptions}

- The participants are truthfully answering the questions to the best of their knowledge and ability. 


\section{Limitations}

- There can be no assurance that the sample, taken over two different presentation sessions, does not include some of the same individuals.

- Because of the anonymous nature of the study there was also no assurance the follow-up surveys reached the same participants that witnessed the presentation as they were simply sent the public health department that they reported they were from for attendance purposes at the continuing education course that hosted the presentation.

- Also, unbeknownst to the researcher, copies of the presentation were supplied to the potential participants prior to the start of the presentation and they therefore had access to information that could have been used to answer the knowledge-based questions.

- Limited reliability and validity of the measurement instruments (surveys) due to limited preliminary testing.

\section{Delimitations}

- The study frame included a convenience sample of public health professionals only from West Virginia attending a continuing education course which enabled results specificity to the state.

- Public healthcare professionals were chosen as subjects in this study due to their knowledge of and proximity to healthcare concerns specific to their patients, the general public. 


\section{Chapter 2: Review of Literature}

\section{Introduction}

Human Papillomavirus (HPV) is a proven cause of a new subset of oropharyngeal squamous cell carcinoma (OSCC) (D'Souza, 2007). Strain 16 is linked to the majority of HPV positive OSCCs and is included in both prophylactic HPV vaccinations (Kriemer, 2005; Food and Drug Administration (FDA), 2009). HPV-associated oropharyngeal cancer rates in West Virginia from 2006-2010 for females were 1.60-1.93 (per 100,000) and for males were 6.09-7.03 (per 100,000) (Centers for Disease Control and Prevention [CDC], 2014). As HPV related oral cancers become more common it is imperative that public healthcare providers are knowledgeable about the connection and are able to advise patients appropriately. There are several screening methods for HPV related oral cancer that can be recommended to at risk patients (males, those that have had more than 6 oral sex partners, or are immunocompromised) (D’Souza G., 2007; Kreimer, 2004; Smith E., 2004). This health concern requires involvement of multiple healthcare disciplines from primary care, dental, and pathology, to oncology. The application of this topic during IPE events, and multidisciplinary educational events that promote responsive and relevant communication to improve patient safety and treatment, could greatly increase familiarity, confidence and inspire a team-based approach (Institute of Medicine, 2010).

\section{Historic Perspectives of HPV}

HPV is currently the most common sexually transmitted disease and is a collection of more than 100 viruses; most strains $(60 \%)$ cause warts or are eliminated by the immune system while the remaining (40\%) can cause cancer (CDC, 2009; American Cancer Society, 2009). It is estimated that HPV is responsible for almost all cervical cancers, $95 \%$ of anal cancers, $65 \%$ of vaginal cancers, $60 \%$ of oropharyngeal cancers, $50 \%$ of vulvar cancers, and $35 \%$ of penile 
cancers (CDC, 2013b). HPV infections can remain unexpressed or latent for 20 years or more, making increased transmission of the HPV virus between sexually active individuals a notable concern as it can be transmitted without any current signs or symptoms (Watson, 2005; McIllhaney, 2000).

\section{HPV Vaccinations}

In 2006, a quadrivirulant vaccine was developed to prevent the four most harmful and prevalent strains of HPV (Food and Drug Administration [FDA], 2014). The vaccine includes strains 6 and 11 (which cause $90 \%$ of genital warts) and strains 16 and 18 (which cause $70 \%$ of cervical cancer). It has been approved for males and females ages nine to twenty six years old and has been proven to be close to $100 \%$ effective when administered before any contact with the viruses (American Cancer Society, 2009; CDC, 2012; FDA, 2009). In 2009, another prophylactic vaccine was introduced and includes HPV16 and 18, therefore only protecting against cervical cancer. The FDA approved the second HPV vaccine for use in males and females ages ten to twenty five years old with an estimated efficacy of $93 \%$ when administered before any exposure to HPV (FDA, 2009).

In 2011 less West Virginia females age 13-17 had received $\geq 3$ of the HPV vaccine trilogy than those in the United States (28.6\% WV, 34.8\% US) (Morbidity and Mortality Weekly Report (MMWR), 2012). However, by 2013 more West Virginian females and males age 13-17 had received $\geq 3$ of the HPV vaccines than nationally (females: $38.4 \% \mathrm{WV}, 37.6 \%$ US; males: $15.1 \%$ WV, 13.9\% US) (MMWR), 2014). From 2007 to present 42,084 West Virginian patients have completed all three injections of either HPV vaccine with 21,589 being done in the private sector and 20,495 in the public sector, which includes health departments. 


\section{Oropharyngeal cancer and HPV}

\section{Risk factors}

Smoking and alcohol use do not increase the risk of HPV16 associated oropharyngeal cancer however, a high lifetime number of vaginal sex partners (twenty six or more) or a high lifetime number of oral sex partners (six or more) was associated with HPV-related oropharyngeal cancer (Applebaum K., 2007; D’Souza et al., 2007). Gonçalves (2006) concluded that patients having lower levels of IgA in their saliva were more susceptible to both genital and oral HPV infections. HPV is known as an opportunistic oral infection and is seen more frequently in the immunocompromised, regardless of level or severity of immunosuppression (Leigh, et al., 1999).

\section{Transmission and Appearance}

Transmission of HPV to the oral cavity is made possible when a viable route or contact (oral sex) occurs and is combined with a suitable environment (oral mucosa) in a susceptible host (sexually active individual) (Syrjanen, 2003). To clarify, the main route of oral HPV transmission is through oral sex, including both fellatio and cunnilingus and some forms of deep kissing (Gillison, 2012; Martin-Hernan, Sanchez-Hernandez, Cano, Campo, \& del Romero, 2013).

Clinically, cancerous lesions on the tonsils can appear as white plaques (leukoplakia), indurated ulcers, or bulky multi-lobed exophytic growths (Weiland, 1997; Young, 2007). These lesions most often occur on the anterior tonsillar pillars (American Cancer Society, 2009; Yanjia, 2007). If HPV is involved, the exophytic growths could look cauliflower-like with multiple lobes and either sessile or pedunculated bases, similar to those seen in genital warts (Syrjanen, 2003). Clinically, a tumor formed in the oropharynx can look very similar, regardless of the carcinogen. 
Therefore the patient's health history and a biopsy of the tumor are the most accurate ways to determine the cause (National Cancer Institute, 2011).

\section{Prognosis}

Oropharyngeal cancer has a 50\% survival rate within the first five years after diagnosis but has increased survival rates when identified and treated earlier (National Cancer Institute, 2011). Although HPV-associated cancers are commonly detected in advanced stages of disease, most cases that contain HPV have a better prognosis with typical radiation or chemotherapy for unknown reasons (Smith E., 2004; D’Souza et al., 2007; Klozar, 2008).

\section{National oral HPV prevalence}

In 2009 nationwide oral HPV prevalence in both males and females ages 14-69 was 6.9\% with HPV 16, the primary cancer causing strain, accounting for $1.0 \%$ with peak prevalence occurring at ages $31-34$ years $(7.3 \%, 95 \% \mathrm{CI}, 4.6 \%-11.4 \%)$ and $60-64$ years $(16.4 \%, 95 \% \mathrm{CI}$, 8.5\%-15.1\%) (Gillison et al., 2012). The incidence of HPV-positive oropharyngeal cancer increased in the United States by $225 \%$, especially in younger populations since the 1950 s (Chaturvedi, 2011).

\section{Oral HPV prevalence in West Virginia}

From 2005-2009 there were 1,263 oropharyngeal cancers in West Virginia, 903 of which were males (WV DHHR, 2012). HPV-associated oropharyngeal cancer rates in West Virginia from 2006-2010 for females were 1.60-1.93 (per 100,000) and for males were 6.09-7.03 (per 100,000) (CDC, 2014).

\section{Early Detection of HPV-associated oropharyngeal cancer}

Although the standard of care dental professionals currently perform oral cancer screenings on a varied basis depending on professional preferences or patient request. These 
screenings include a visual exam of all sides of the tongue, buccal mucosa of the cheeks, vestibular mucosa and palpation of the floor of the mouth and lymph nodes along the neck (Sapp, 2004). This type of screening tends to be useful for identifying visible or palpable changes in the mucosa consistent with a cancerous lesion, however visible lesions tend to be identified in the later stages of metastasis (D’Souza G., 2007). Palpation searches for nodular formations are often inconclusive considering there are enumerable other less-threatening nodular formations such as swollen lymph nodes due to allergies or colds, mucoceles, sialoliths, or draining fistulas which are unrelated to oral cancer (Sapp, 2004). Likewise, blood titers would be able to identify a positive result for HPV antibodies which could indicate the presence of the HPV vaccine or natural resistance to a past or current infection and therefore would not be useful as an HPV screening tool specific to the oral cavity.

Salivary diagnostics have quickly been recognized by the medical community as an easy and less invasive way to collect DNA samples for many uses. Salivary diagnostics are now able to detect the presence of HPV strains in the oral cavity. Many companies now boast a specific HPV test that uses the patient's saliva either through a saline rinse or a saliva soaked cotton patch (Shirtcliff, 2001). Most tests work by utilizing Polymerase Chain Reaction (PCR) assays which identify specific viral DNA strands (Walline, et al., 2013).

A new handheld device uses fluorescence technology to identify submucosal cellular changes by exposing a normal or suspicious intra-oral area to blue wavelength visible light. Normal tissues glows apple green under the blue light while areas with cellular changes will appear dull, darkened or sometimes dark brown (Thong, 2009). This development enables dental professionals to non-invasively screen patients for submucosal changes that are not clinically 
visible. Although the test is efficient at identifying cellular changes, it is not specific to the cause of cellular changes and therefore requires additional diagnostic tests.

\section{Behavior Change Models and Interprofessional Education}

According to several social and behavioral change models the first stage typically addresses the presence or lack of knowledge. Specifically, the Knowledge-Attitude-Behavior model and the Health Belief model rely on current knowledge level to influence attitudes, perceived susceptibility and perceived seriousness (Baronowski, 2003; Griffith, 2011). Thus, health care providers must be knowledgeable to impart adequate instructions to patients to enable their patients to make informed health decisions. As education concerning oral cancers related to HPV concerns many health disciplines it would be an ideal topic for interprofessional education (IPE) and collaborations.

IPE was developed to aid in the sharing of pertinent health information by inviting multiple disciplines to educational events to improve collaboration and quality of patient care (WHO, 2010). The core competencies of IPE guide many collaborative efforts and are as follows:

1. Work with individuals of other professions to maintain a climate of mutual respect and shared values;

2. Use the knowledge of one's own role and those of other professions to appropriately assess and address the healthcare needs of the patients and populations served;

3. Communicate with patients, families, and communities, and other health professionals in a responsive and responsible manner that supports a team approach to the maintenance of health and the treatment of disease; 
4. Apply the relationship-building values and the principles of team dynamics to perform effectively in different team roles to plan and deliver patient/population-centered care that is safe, timely, efficient, effective, and equitable (IPE Collaborative Expert Panel, 2011).

While the idea of IPE faces many intrinsic and extrinsic challenges studies suggest there is potential for improvements in patient health and safety to occur as a result of this collaboration (Coleman, 2005; Thistlethwaite, 2012).

Some advocate the combining of continuing education with IPE to create continuing interprofessional education (CIPE). The combination training would not only provide continuing education at more routine intervals but could encourage multidisciplinary working relationships. New knowledge is retained best when presented on a contracting schedule or at decreasing intervals from introduction to examination (Kupper-Tetzel, Kapler, Wiseheart, 2014). Regardless of educational schedule knowledge retention has been shown to decline approximately 20-30\% in 35 days (Kupper-Tetzel, Kapler, Wiseheart, 2014). Furthermore, knowledge retention decreases substantially with nonpractices or nonuse especially for cognitive and accuracy-based tasks (Arthur, Bennett, Stanush, McNelly, 1998). 


\section{Chapter 3: Procedures and Methodology}

\section{Introduction}

Annually, West Virginia's public health professionals gather for the purpose of obtaining continuing education for state and national licensure requirements. These events were not CIPE or IPE events although several disciplines were present. Continuing education events became the venues for the study due to the ability to convenience sample public health professionals and present the educational intervention. The survey method of information gathering was selected due to its ability to be quick administration, anonymous nature and ease of use.

Three surveys were designed to be administered before, immediately after and four months after an educational presentation during a public health continuing education seminar. Surveys included dichotic, multiple choice and multiple-multiple choice questions. Surveys also included Likert-scale questions designed to describe attitudes, with five answer choices that ranged from Strongly Agree to Strongly Disagree. These questions had similar format to knowledge, attitude and perception surveys therefore having similar reliability and validity. Surveys were critiqued by corrected by several faculty involved in survey research.

In this study a pre- and post- intervention survey method was utilized with an additional mailed survey that is identical to the post-intervention survey [Appendix A: Surveys]. The preintervention survey gathered demographic data and established knowledge and perceived behavioral habits. The post-intervention and mailed follow-up survey were identical and designed to establish knowledge gain and/or retention over time as well as attitude or perceived behavioral changes. 


\section{Procedures}

Implementation of this study began with introduction of the study to those present and the anonymous nature and IRB compliance was explained. Although the presentation was scheduled with the nursing section of the continuing education event, other available disciplines were invited to attend. The study was not included on the continuing education events' itinerary but the slides were printed beforehand and given to the participants.

Implied consent was expressed by participants completing the surveys after having read the cover letter. The intervention, an educational ten minute Powerpoint presentation, was provided between the pre- and post-intervention surveys. Participants were given five to ten minutes to complete each survey during the 30 minute presentation time slot.

At the close of the presentation, a question and answer session covering presented content was conducted and surveys were collected. Informational handouts on oral cancer related to HPV were provided after the presentation along with the 'Oral Cancer' brochure available from the National Health Institute to interested participants. A volunteer from the event's management of the continuing education event provided a numerical list of public health professionals attending the lecture from each health departments represented. This information was utilized to mail the follow-up survey to potential participants.

The follow-up survey with prepaid return postage was sent via postal service to their respective health departments. As their names were unknown it was taken upon the mail reviewer at each health department to deliver the survey to the actual participant. A cover different letter included directions, a short explanation of the study, and reiteration of the anonymous nature were included with the follow-up survey. Responding participants were mailed a fifteen dollar gift card from their choice of four pizza restaurants. 


\section{Subjects}

All participants were above the age of 18 . The participants of this study consisted of a convenience sample of public health professionals, including any clinical and non-clinical health related profession, employed at one of 53 public health departments within the state of West Virginia.

\section{Statistical Analysis}

Descriptive statistics were utilized to achieve an overall picture of their patients' demographics and determine if these patients fit the predetermined at-risk populations. Participant demographics and overall trends in frequently selected answers were also described using descriptive statistics. One variable was created to ascertain differences within the sample between answer choices of nurses versus non-nurses.

Five questions appeared on all three surveys; three knowledge based questions and two Likert-scale questions. All questions were analyzed on participants' positive response, i.e. answered correctly on the knowledge questions or answered strongly agree on the attitude questions. The chi square test of independence was selected for use due to its ability to measure association of dichotomous answer choices to the nursing variable. An alpha level of 0.05 was used for all statistical tests and Fisher's p-value was reported when values were less than five.

Binary logistic regression was used to predict relationships between nurses answer choices on all three surveys simultaneously. For all logistic regression the degrees of freedom were equal to one. The chi-square value reported with the logistic regression results was the Wald statistic. 


\section{Chapter 4: Results}

\section{Descriptive Data}

The seventy five participants represented 33 health departments and seven public health agencies within West Virginia. This sample represents approximately $20 \%$ of the total community health workers and $62 \%$ of state health departments (United States Department of Labor, 2014). The mailed follow up surveys had a response rate of $48 \%$ from the first session, $95 \%$ from the second session for a combined response rate of $76 \%$. The majority of participants were nurses, ages 40-59 with either an Associate's degree or above (see Figure 1.1).

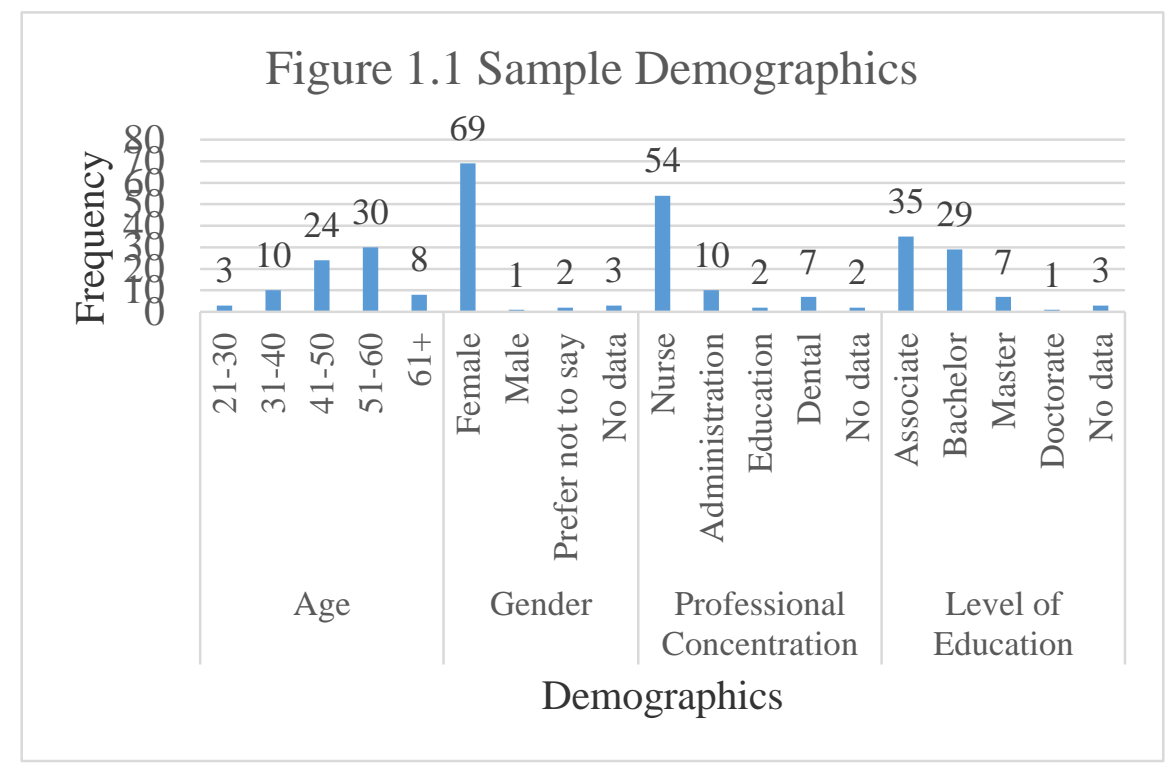

Perceptions about the populations served by participants were gathered on the preliminary survey. Practitioners estimated that of the patients they see approximately $10-50 \%$ of them have been diagnosed with HPV and approximately $70 \%$ of their patients are under 30 years old. Slightly under half of participants (46\%) stated they spend less than $10 \%$ or between 10 $30 \%$ of their time speaking with patients about HPV however, 34\% stated they recommend the 
HPV vaccines anywhere from $30-70 \%$ of the time. In addition, $20 \%$ stated they recommend the vaccines less than $10 \%$ of the time while $21 \%$ of participants stated they recommend HPV vaccinations $90-100 \%$ of the time (see Figure 1.2).

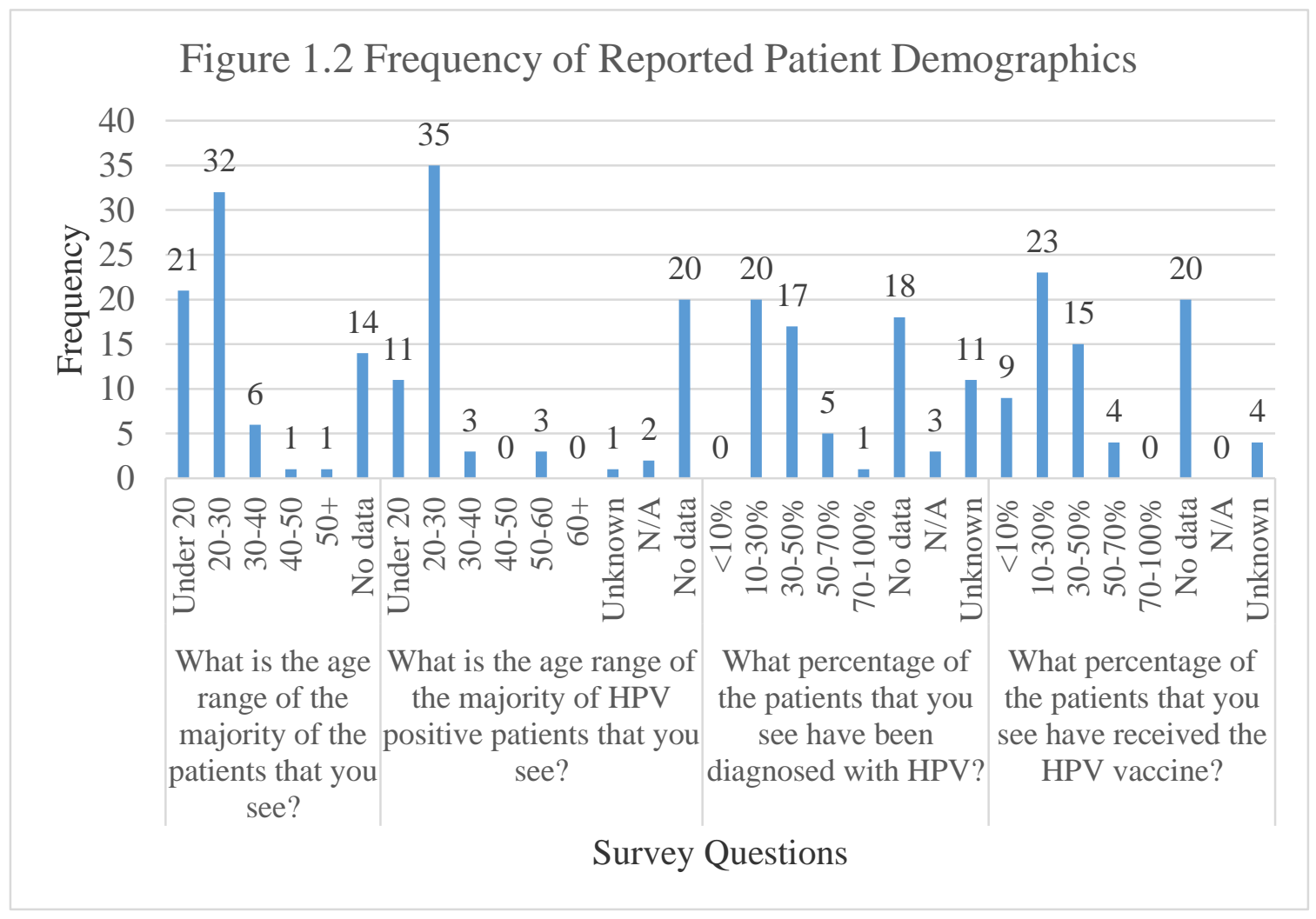

The overall frequency of correctly answered knowledge based questions decreased from the pre-intervention to the follow-up survey for the entire sample. One attitude question showed a similar decline of favorable agreement with the statement. Conversely, Question 5 showed an increase of agreement to the statement by 20 responses. 


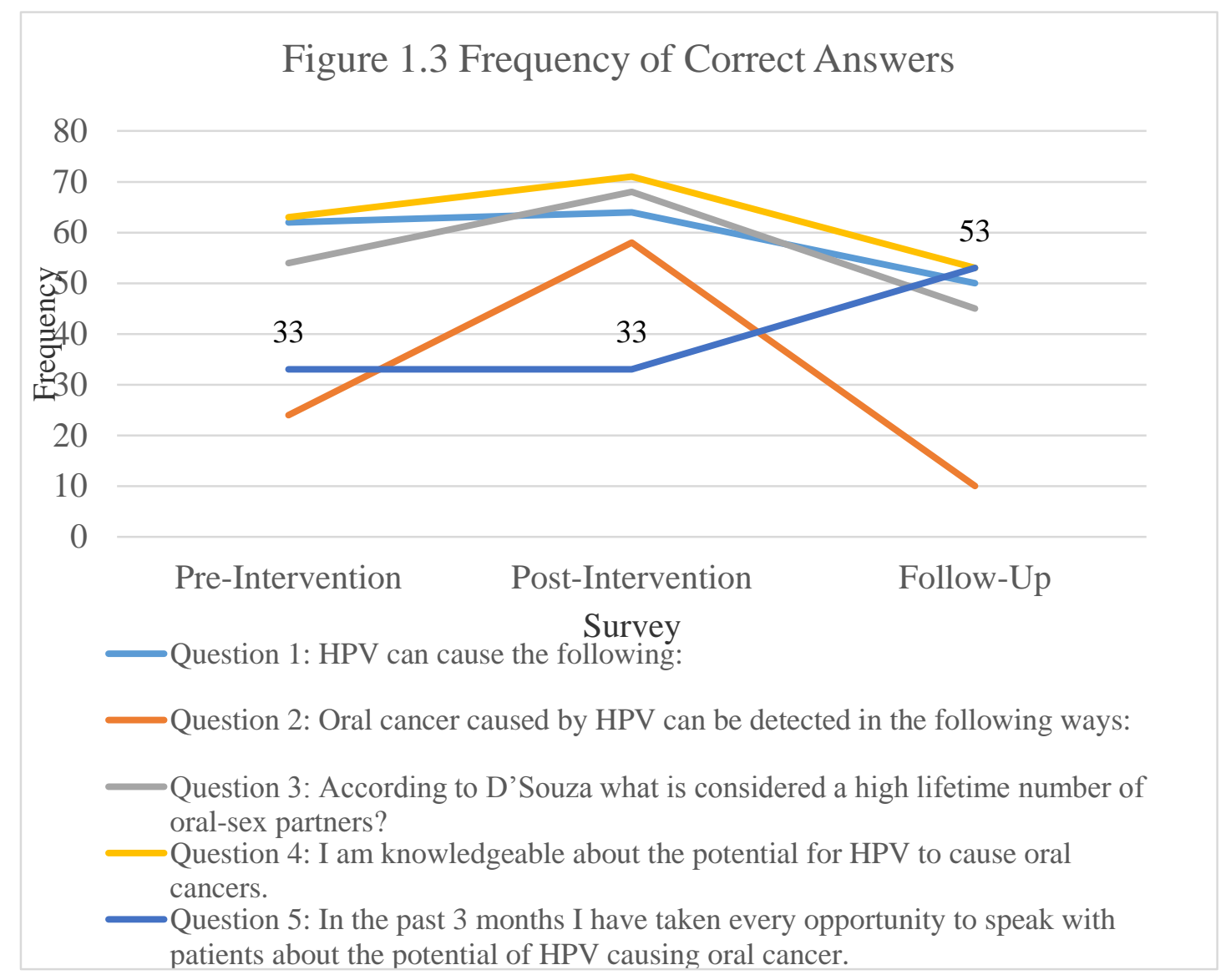

\section{Chi Square test for Independence}

A chi square test of independence was performed to determine the possible relationships between nurses' answers on each of the consistent five questions. Results indicate that nursing professionals were more likely to answer Question 1 and Question 3 correctly on the follow up survey than non-nurses, $\mathrm{X} 2=6.48, \mathrm{p}=0.03, \mathrm{X} 2=6.32, \mathrm{p}=0.02$, respectively. Similarly, they were more likely to answer Question 2 correctly on the pre-intervention survey, $X 2=4.51, \mathrm{p}=0.05$. Nurses were more likely to strongly agree with the fifth consistent question on the follow up survey than other professions, $\mathrm{X} 2=14.51, \mathrm{p}=0.0001$. Nurses' agreement to the statement 
describing their perceived patient education behaviors in the last three months increased over time, Figure 2.1.

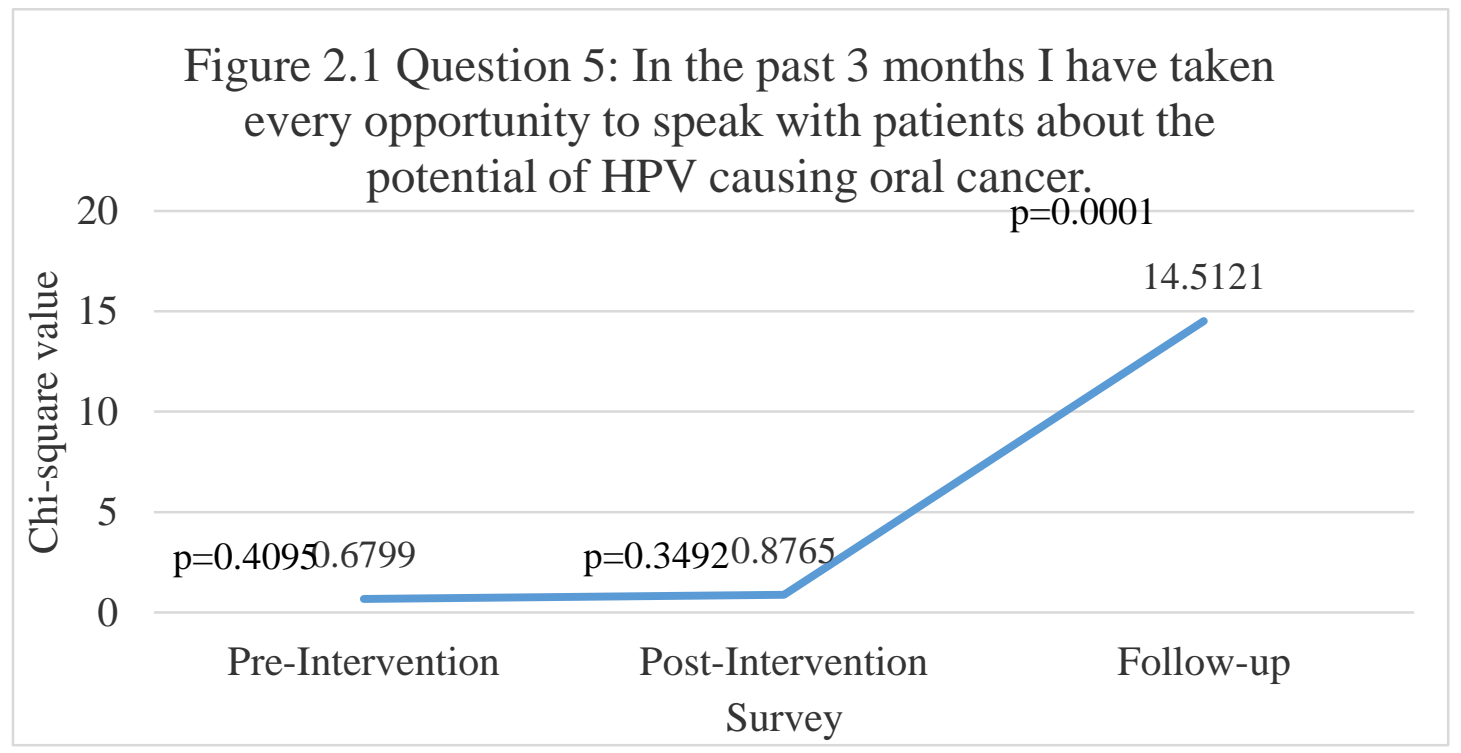

Chi-square analysis of attitude questions did not reveal any statistically significant relationships. For all attitude questions, except the second question, there was some degree of increased agreement determined by the increase in chi-square values on the follow up surveys. The second attitude question asked if professional behaviors were likely to be affected as a result of the lecture. Initially nurses agreed with the statement $(\mathrm{X} 2=3.6, \mathrm{p}=0.06)$ but agreement decreased on the follow up $(\mathrm{X} 2=1.1, \mathrm{p}=0.48)$.

\section{Binary Logistic Regression}

The predictive model indicated that the variable for nurses was significantly different than the model on Question 4 of the follow up survey $(\mathrm{X} 2=5.3 \mathrm{p}=0.02, \mathrm{OR}=6.2)$. For the remainder of consistently asked questions the logistic regression results suggest no statistically significant changes occurred before, after or 4 months after presenting the informational presentation (Appendix: Table 3). 


\section{Chapter 5: Discussion and Conclusions}

\section{Summary of Findings}

Overall, the statistical analysis of all three surveys may support the research hypothesis stating that changes in knowledge and attitude have occurred because of exposure to the informational presentation. The most profound result of this study indicates that the presentation encouraged $71 \%$ of the sample to change their behavior and are now educating their patients more about oral cancers related to HPV. This result could be used to encourage future interprofessional education events on this topic to help continue to improve communication with patients, families, communities and other professionals.

\section{Discussion}

The frequency data reveals a possible contradiction between the responses. Approximately half of the responses indicated that they recommend the HPV vaccination 90$100 \%$ of the time while the other half indicated they recommend it less than $10 \%$. A noticeable trend in the data was nonresponse for clinical based questions meant for nurses only. Nonresponse accounted for approximately $25 \%$ of responses even though an 'Unknown' option was included for all of those questions.

The chi square results for two of the three consistently asked knowledge based questions increased over time from the pre-intervention survey to the follow-up. The significant increase suggests an improvement on previously held knowledge. While overall knowledge of nurses increased over time the observed effect may be, in part, due to the reuse of the post-survey as the follow-up survey thereby possibly creating familiarity and false positive results. The one instance where knowledge level decreased over time may suggest that some information presented in the lecture was unclear. This decrease could also reassure that the results were not 
subject to bias created by question familiarity. Statistical analysis of attitudes toward perceived knowledge on the topic were inconclusive and may suggest an uncertainty of their knowledge level.

Chi square analysis of the attitude questions included on the post-intervention and follow up surveys showed improvement although not statistically significant. After the educational presentation participants indicated they were more likely to engage and educate the public about oral cancer caused by HPV and encourage their at-risk patients to seek oral cancer screenings. This slight change in behavior indicates the potential impact of IPE on current heath care topics. Communication in all areas, between all individuals, is integral to achieving the goals of IPE. The results of this study indicate that this level of communication is not only possible but is able to encourage behavior change.

Binary logistic regression revealed only one significant increase over time. Nurses’ felt stronger about their knowledge of oral cancers related to HPV over time which could be due to the information presented in the lecture or additional information sought in the time between the post-intervention survey and the follow-up survey. Logistic regression results were unable to be run on the post-intervention survey responses to Question 3 of the consistently asked questions due to model redundancy or an unexpectedly homogenous result; ninety one percent or 68 of 75 participants answered this question correctly immediately following the lecture.

\section{Conclusions}

- Study results suggest the educational presentation had an overall positive effect on the participants' knowledge, attitudes and behaviors. 
- Participants have exhibited significant behavior change following the educational presentation specifically, $70 \%$ of participants are now educating their patients about the oral cancers related to HPV compared to $44 \%$ pre-intervention.

- Retention of the knowledge over four months' time was demonstrated on two of the three knowledge based questions. The indication that some knowledge was retained is encouraging but necessitates the need for future CIPE or IPE on this same topic.

\section{Recommendations for Further Research}

- Alterations of the same study design (one long in-depth educational presentation or a series of several small presentations over differing intervals of time with similar surveys) could better describe knowledge retention of this population.

- The incorporation of a hands-on component, patient-communication tips for chairside education or development of discussion aids for patient education could encourage better knowledge retention through practical, kinesthetic learning.

- Additional research could be done to discover the possible impact of public health professionals' chairside education and their recommendations of the HPV vaccines on the prevalence of oral cancers related to HPV. The application of this topic to CIPE for other healthcare settings such as those in correctional institutions or Native American reservations has yet to be explored. 


\section{References}

Adams, M. J. (2007). Human papillomaviurs (HPV) prophylactic vaccination: Challenges for public health and implications for screening. Vaccine.

American Cancer Society. (2009). Cancer Reference Information. Retrieved from Detaild guide: oral cavity and oropharyngeal cancer, what are the risk factors for oral cavity and oropharyngeal cancers?:

http://www.cancer.org/docroot/CRl/content/CR1242xWhataretheriskfactorsfororalcavitya ndoropharyngealcancer60.asp? sitearea $=\mathrm{CRl}$

American Cancer Society. (2009). Human papillomavirus (HPV), cancer and HPV vaccines. Retrieved from Frequently Asked Questions: www.cancer.org/docroot/CR1/content?CR126xFaqHPVVaccines.asp

American Nurses Assocaition \& National Association of School Nurses. (2011). Scope and Standards of practice - School nursing. Silver Spring, MD: Nursebooks.org.

American Public Health Association. (2014). About. Retrieved from What are public health professionals?: http://www.apha.org/about/donate/What+do/

American Social Health Association. (2009). HPV and cervical cancer prevention. Retrieved from HPV vaccines: www.ashastd.org/hpv/hpvvacines.cfm

Arthur, W., Bennett, W., Stanush, P., \& McNelly, T. (1998). Factors that influene skill decay and retention: A quanitative review and analysis. Human Performance, 57-101.

Applebaum K., F. C. (2007). Lack of Association of Alcohol and Tobacco with HPV 16Associated Head and Neck Cancer. Journal of national Cancer Institute.

Cates, J., Brewer, N., Fazekas, K., Mitchell, C., \& Smith, J. (2009). Racial differences in HPV knowledge, HPV vaccine acceptability, and related beliefs among rural, sourthern women. The Journal of Rural Health.

Center for Disease Control. (2009). CDC genital HPV infection. Retrieved from CDC Fact Sheet: www.cdc.gov/std/HPV/STDFact-HPV.html

Center for Disease Control. (2012, December 22). Vaccines and Immunizations. Retrieved from HPV Vaccines: Questions and Answers: www.cdc.gov/vaccines/vpd-vac/hpv/vacfaqs.htm

Centers for Disease Control and Prevention. (2002). Trends in sexual risk behaviors among high school students - Unitied States, 1991-2001. MMWR, 856-9. 
Centers for Disease Control and Prevention. (2012, April 20). Centers for Disease Control and Prevention. Retrieved from Morbidity and Mortality Weekly Report; Human

Papillomavirus-associated cancers: United States 2004-2008:

http://www.cdc.gov/mmwr/preview/mmwrhtml/mm6115a2.htm

Centers for Disease Control and Prevention. (2013, July 18). Centers for Disease Control and Prevention. Retrieved from Human Papillomavirus (HPV) Associated Cancers: http://www.cdc.gov/cancer/hpv/statistics/cases.htm

Centers for Disease Control and Prevention. (2013, September 5). Centers for Disease Control and Prevention. Retrieved from Human papillomavirus (HPV) associated cancers; HPV associated oropharyngeal cancer rates by state: http://www.cdc.gov/cancer/hpv/statistics/state/oropharyngeal.htm

Chaturvedi A, E. E. (2011). Human papillomavirus and riseing oropharyngeal cancer incidence in the United States. Journal of Clinical Oncology, 4294-4301.

Chuang, A. C. (2008). Presence of HPV DNA in covalescent salivary rinses is an adverse prognostic marker in head and neck squamous cell carcinoma. Oral Oncology, 915-9.

Coutlee R., T. A. (1997). Risk factors for oral human papillomavirus in adutls infected and not infected with human innunodeficiency virus. Sexually Transmittable Diseases, 23-31.

D'Souza, G., Kreimer, A., Viscidi, R., Pawlita, M., Fakhry, C., Koch, W., . . Gillison, M. (2007). Case-control study of human papillomavirus and oropharyngeal cancer. New England Journal of Medicine.

Dunne, E., Sternberg, M., Markowitz, L., McQuillan, G., Swan, D., Patel, S., \& Unger, E. (2011). Human papillomavirus (HPV) 6, 11, 16, and 18 prevalence among females in the United States - National health and nutrition examination survey, 2003-2006:

Opportunity to measure HPV vaccine impact? Journal of Infectious Diseases, 204, 562565.

Dunne, E., Unger, E., \& Sternberg, M. (2007). Prevalence of HPV infection among females in the United States. Journal of American Medical Association, 813-819.

Finer, L. (2007). Trends in premarital sex in the United States, 1954-2003. Public Health Reports, 122(7), 73-78.

Food and Drug Administration. (2013, November). Cervarix vaccine. Retrieved from Vaccines, Blood and Biologics: http://www.fda.gov/biologicsbloodvaccines/vaccines/approvedproducts/ucm186957.htm 
Food and Drug Administration. (2014). Gardasil vaccine. Retrieved from Vaccines, Blood and Biologics: http://www.fda.gov/BiologicsBloodVaccines/Vaccines/ApprovedProducts/UCM094042

Friedman, A., \& Shepeard, H. (2007). Exploring the knowledge, attitudes, beliefs, and communication preferences of the general public regarding HPV: findings from the CDC focus group research and implications for practice. Health Education and Behavior, 34(3), 471-85.

Fukucchi E., S. G. (2009). Cervical human papillomavirus incidence and persistence in a chohort of HIV-negative women in Zimbabwe. Sexually Transmittable Diseases, 305-11.

Gillison, M., Broutain, T., Pickard, R., Tong, Z., Xiao, W., Kahle, L., . . Chatuvedi, A. (2012). Prevelance of oral HPV infection in the United States, 2009-2010. Journal of the American Medical Association, 693-703.

Gillison, M., Chaturvedi, A., \& Lowy, D. (2008). HPV prophylactic vaccines and the potential prevention of noncervical cancers in both men and women. Cancer, 113(10 (Suppl)), $3036-46$.

Gillson, M., D'Souza , G., \& Westra, W. (2008). Distinct risk factor profiles for human papillomavirus type 16-positive and human papillomavirus type 16-negative head and neck cancers. Journal of the National Cancer Institute, 100(6), 407-420.

GlaxoSmithKline. (2009, October 16). FDA approves Cervarix. Retrieved from GlaxoSmithKline's cervical cancer vaccine: http://www.gsk.com/media/pressreleases/2009/2009_pressrelease_10112.htm

Goncalves, A. G.-M. (2006). Secretory immunoglobulin A in saliva of women with oral and genital HPV infection. Eurpoean Journal of Obstetrics and Gynocology and Reproductive Biology, 227-31.

Hansson BG., R. K. (2005). Strong association between infections with human papillomavirus and oral and oropharyngeal squamous cell carcinoma: a population-based case-control study in southern Sweden. Acta Otolaryngol, 1337-44.

Haymarket Media. (2014). Chemotherapy Advisor. Retrieved from HPV-associated oropharyngeal cancer: A growing dilemma.: http://www.chemotherapyadvisor.com/hpvassociated-oropharyngeal-cancer-a-growing-dilemma/article/283982/

Hu, D., \& Goldie, S. (2008, May). The economic burden of noncervical human papillomavirus disease in the United States. American Journal of Obstetrics and Gynecology, 198(5), 500.e1-500e.7. 
Interprofessional Education Collaborative Expert Panel. (2011). Core competencies for interprofessional collaborative practice: Report of an expert panel. Interpforessional Education Collaborative, 1-56.

Institute of Medicine (IOM) (2010). Redesigning continuing education in the health professions. Washington DC: National Acedemies Press.

Juraskova, I., O'Brien, M., Mullan, B., Bari, R., Laidsaar-Powell, R., \& McCaffery, K. (2011). HPV vaccination and the effect of information framing on intentions and behaviour: An application of the theory of planned behavior and moral norm. International Society of Behavioral Medicine, 19, 518-525.

Khubchandani, J., Telliohann, S., Price, J., Dake, J., \& Hendershot, C. (2013). Providing assistance to the victims of adolescent dating violence: A national assessment of school nurses' practices. Journal of School Health, 83(2), 127-136.

Kreimer, A. A. (2004). Oral human papillomavirus infection in adults is associated with sexual behavior and HIV serostatus. Journal of Infectious Diseases, 686-698.

Kriemer A., C. G. (2005). Human papillomavirus types in head and neck squamous cell carcinomas worldwide: A systematic review. Cancer Epidemiology, Biomarkers, and Prevention.

Leigh, I., Buchanan, A., Harwood, C., Cerio, R., \& Storey, A. (1999). Role of Human papillomaviruses in cutaneous and oral manifestatios of immunosuppression. Journal of Acquired Immune Deficiency Syndromes, 21, 849-857.

Martin-Hernan, F., Sanchez-Hernandez, J., Cano, J., Campo, J., \& del Romero, J. (2013). Oral cancer, HPV infection and evidence of sexual transmission. Medicana Oral Patolgia Oral y Cirugia Bucal, 1(18), 439-444.

Marur, S., D'Souza, G., Westra, W., \& Forastiere, A. (2010). HPV- associated head and neck cancer: A virus-related cancer epidemic. The Lancet Oncology, 11, 781-789.

Mays, R. Z. (2004). Recommending STI vaccination to parents of adolescents: The attitudes of nurse practitioners. Sexually Transmitted Diseases, 428-32.

Morbidity and Mortality Weekly Report. (2012, August 31). Retrieved from National and State Vaccination Coverage Among Adolescents Aged 13-17 Years - United States, 2011: http://www.cdc.gov/mmwr/preview/mmwrhtml/mm6134a3.htm

Morbidity and Mortality Weekly Report. (2014, July 25). Retrieved from National, Regional, State, and Selected Local Area Vaccination Coverage Among Adolescents Aged 13-17 
Years - United States, 2013:

http://www.cdc.gov/mmwr/preview/mmwrhtml/mm6329a4.htm

National Cancer Institute. (2008, August 9). HPV status and oral cancer outcome. Retrieved from HPV Status Can Predict Outcome in Oropharyngeal cancer:

http://www.cancer.gov/cancertopics/types/oral

National Cancer Institute. (2011, October 21). Oropharyngeal Cancer Treatment. Retrieved from Genearl information about oropharyngeal cancer: http://www.cancer.gov/cancertopics/pdq/treatment/oropharyngeal/Patient/page1

NHS. (n.d.). Health \& Social Care Information Centre. Retrieved from Community Health Services Statistics: http://www.cnhs.uk/

Peto, J. G. (2004). The cervical cancer epidemic that screening prevented in the UK. The Lancet Oncology, 249-56.

Pryjmachuk, S., Graham, T., Haddad, M., \& Tylee, A. (2011). School nurses' perspectives on managing mental health problems in children and young people. Journal of Clinical Nursing, 21, 850-859.

Sayyahh-Melli, M. K.-S.-T.-S.-G. (2011). Detection of human papillomavirus in the saliva of women with concurrent human papillomavirus related genital lesions. Saudi Medical Journal, 141-6.

Shaha, M., Wenzel, J., \& Hill, E. (2011). Planning and conducting focus group research with nurses. Nurse Researcher, 18(2), 77-87.

Shiboski, C., Schmidt, B., \& Jordan, R. (2005). Tongue and tonsil carcinoma. Increasing trends in the US population ages 20-44 years. Cancer, 103(9), 1843-1849.

Smith E., R. J. (2004). Age, sexual behavior and human papillomavirus infection in oral cavity and oropharyngeal cancers. International Journal of Cancer.

Smith, E., Rubenstein, L., Haugen, T., Hamsikova, E., \& Turek, L. (2010). Tobacco and alcohol use increases the risk of both HPV-associated and HPV-independent head and neck cancers. . Cancer Causes Control, 21, 1369-78.

Standfort, J. P. (2009). Knowledge, attitudes, and informal behaviors of college students in regard to the human papillomavirus. Journal of American College Health, 141-9.

Steele, R., Wu, Y., Jensen, C., Pankey, S., Davis, A., \& Aylward, B. (2011). School nurses' perceived barriers to discussing weight with children and their families: A qualitative approach. Journal of School Health, 81(3), 128-137. 
Sussman, A., Helitzer, D., Sanders, M., Urquieta, B., Salvador, M., \& Ndiaye, K. (2007). HPV and cervical cancer prevention counseling with younger adolescents: Implications for primary care. Annals of Family Medicine, 5(4), 298-304.

Syrjanen, S. (2003). Human papillomavirus infections and oral tumors. Medical microbiology and immunology, 192(3), 123-128.

United States Census Bureau. (2014, January 6). United States Census Bureau. Retrieved from State \& County QuickFacts, West Virginia: http://quickfacts.census.gov/qfd/states/54000.html

Vail-Smith, K. W. (1992). Risk level, knowledge, and prevenative behavior for human papillomaviruses among sexually active college women. Journal of Collaborative Health, 227-30.

Walline, H., Kormarck, C., McHugh, J., Byrd, S., Spector, M., Hauff, S., . . Carey, T. (2013). High-risk Human papillomavirus detection in oropharyngeal, nasopharyngeal, and oral cavity cancers: Comparison of multiple methods. JAMA Otolaryngol Head and Neck Surgery, 139(12), 1320-1327.

Wamai, R., Ayissi, C., Oduwo, G., Perlman, S., Welty, E., Welty, T., .. Ogembo, J. (2013). Awareness, knowledge and beliefs about HPV, cervical cancer and HPV vaccines among nurses in Cameroon: An exploratory study. International Journal of Nursing Studies, 50, 1399-1406.

Weinstock, H., Berman, S., \& Cates, W. (2004). Sexually transmitted diseases among American youth: incidence and prevalence estimates, 2000. Perspective Sexual Reproductive Health, 36(1), 6-10.

West Virginia Board of Education. (2013). 2013 West Virginia School Nurse Directory. West Virginia.

West Virginia Department of Health and Human Resources. (2010). West Virginia Oral Health Plan 2010-2015. Charleston: Bereau for Public Health.

West Virginia Department of Health and Human Resources. (2012). West Virginia Cancer Registry; 2012 Annual Report. Charleston: Bureau for Public Health.

Wieland U., P. H. (1997). Papillomavirus in human pathology: epidemiology, pathogenesis and oncogenic role oral. 399-412.

Yacobi, E. T. (1999). University students' knowledge and awareness of HPV. Preventive Medicine, 535-41. 
Zhao M., R. E. (2005). Feasibility of quanitative PCR-based saliva rinse screening of HPV for head and neck cancer. International Journal of Cancer, 605-10. 


\section{Appendix A: Surveys}

Instructions: Please circle the answer that fits you and your beliefs the best. Answers to this survey are anonymous. In no way will these surveys be linked to you or affect your job.

$\begin{array}{llllrr}\text { Age: } & \text { Under } 20 & 21-30 & 31-40 \quad 41-50 & 51-60 & 61+ \\ \text { Gender: } & \text { Male } & \text { Female } & \text { Prefer not to say } & \end{array}$

Region: I II III IV V VI

Professional Concentration: Administration Education Dental Nursing Other:

Highest Level of Education: High School Diploma Associate Bachelor Master Doctorate Other:

1. What is the age range of the majority of patients that you see?

Under $20 \quad 20-30 \quad 30-40$

\section{Circle all that apply;}

$$
40-50 \quad 50-60 \quad 60+
$$

2. I talk with patients about HPV what percentage of the time?

$\begin{array}{lllll}<10 \% & 10-30 \% & 30-50 \% & 50-70 \% & 70-100 \%\end{array}$

3. What percentage of the patients that you see do you recommend the HPV vaccines to?

$\begin{array}{lllll}<10 \% & 10-30 \% & 30-50 \% & 50-70 \% & 70-100 \%\end{array}$

If you are not a nurse you may skip to \# 7.

4. What is the age range of the majority of HPV positive patients that you see?

N/A Under 20 20-30 30-40

40-50 50-60 60+ Unknown

5. What percentage of the patients that you see have been diagnosed with HPV?

$$
\begin{array}{ccc}
\text { N/A } & 10-30 \% & 30-50 \% \\
50-70 \% & 70-100 \% & \text { Unknown }
\end{array}
$$

6. What percentage of the patients that you see have received the HPV vaccine?

$\begin{array}{lllll}<10 \% & 10-30 \% & 30-50 \% & 50-70 \% & 70-100 \%\end{array}$

$$
\text { Unknown }
$$

\section{Circle all that apply;}

HPV can cause the following:
a) cervical cancer
b) no signs or symptoms
c) genital warts
d) oral cancer

\section{Oral cancer caused by HPV can be detected in} the following ways:
a) salivary rinse
b) blue light
c) biopsy
d) by feel
e) blood titers
f) visually

9. According to D'Souza, what is considered a high lifetime number of oral-sex partners?
a) 1-3
b) $4-6$
c) $7-9$

10. I am knowledgeable about the potential of HPV to cause oral cancer.
a) Strongly Agree
b) Agree
c) Undecided
d) Disagree
e) Strongly Disagree

11. In the past 3 months I have taken every opportunity to speak with patients about the potential of HPV causing oral cancer.
a) Strongly Agree
b) Agree
c) Undecided
d) Disagree
e) Strongly Disagree 
Instructions: Please circle the answer that fits you and your beliefs the best. Answers to this survey are anonymous. In no way will these surveys be linked to you or affect your job.

$\begin{array}{lllrrr}\text { Age: } & \text { Under } 20 & 21-30 & 31-40 & 41-50 & 51-60\end{array}$

Gender: $\quad$ Male $\quad$ Female Prefer not to say

Region: I II III IV V VI

Professional Concentration: Administration Education Dental Nursing Other:

Highest Level of Education: High School Diploma Associate Bachelor Master Doctorate Other:

1. Circle all that apply;

HPV can cause the following:
a) cervical cancer
b) no signs or symptoms
c) genital warts
d) oral cancer

\section{Circle all that apply;}

Oral cancer caused by HPV can be detected in the following ways:
a) salivary rinse
b) by feel
c) blue light
d) biopsy
e) blood titers
f) visually

3. According to D'Souza, what is considered a high lifetime number of oral-sex partners?
a) 1-3
b) $4-6$
c) 7-9

4. I am knowledgeable about the potential of HPV to cause oral cancer.
a) Strongly Agree
b) Agree
c) Undecided
d) Disagree
e) Strongly Disagree

6. The lecture on HPV and oral cancer will affect my personal behaviors.
a) Strongly Agree
b) Agree
c) Undecided
d) Disagree
e) Strongly Disagree

7. The lecture on HPV and oral cancer will affect my professional behaviors.
a) Strongly Agree
b) Agree
c) Undecided
d) Disagree
e) Strongly Disagree

8. In the future I will engage and educate the public about the link between HPV and oral cancer to my patients.
a) Strongly Agree
b) Agree
c) Undecided
d) Disagree
e) Strongly Disagree

9. After this course, I will encourage more of my patients with a high lifetime number of sexual partners to have oral cancer screenings.
a) Strongly Agree
b) Agree
c) Undecided
d) Disagree
e) Strongly Disagree

10. In the past 3 months I have taken every opportunity to speak with patients about the potential of HPV causing oral cancer.
a) Strongly Agree
b) Agree
c) Undecided
d) Disagree
e) Strongly Disagree

11. Would you like additional information related to HPV and its implications on oral health?
a) Yes
b) No 
Follow up Survey

Preferred Pizza Gift Card: $\square$ Pizza Hut $\square$ Papa John's $\square$ Fox's Pizza Den $\square$ Dominos

Instructions: Please circle the answer that fits you and your beliefs the best. Answers to this survey are anonymous. In no way will these surveys be linked to you or affect your job.

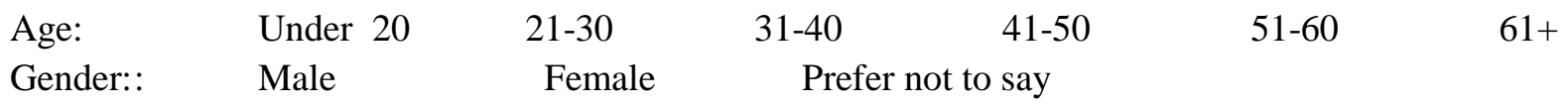

County:

Professional Concentration: Administration Education Dental Nursing Other:

Highest Level of Education: High School Diploma Associate Bachelor Master Doctorate Other:

1. Circle all that apply;

HPV can cause the following:
e) cervical cancer
f) no signs or symptoms
g) genital warts
h) oral cancer

\section{Circle all that apply;}

Oral cancer caused by HPV can be detected in the following ways:
g) salivary rinse
h) by feel
i) blue light
j) brush biopsy
k) blood titers
1) visually

3. According to D'Souza, what is considered a high lifetime number of oral-sex partners?
d) $1-2$
e) $3-5$
f) 6 or more

4. I am knowledgeable about the potential of HPV to cause oral cancer.

f) Strongly Agree

g) Agree

h) Undecided

i) Disagree

j) Strongly Disagree

5. The lecture on HPV and oral cancer affected my personal behaviors.
f) Strongly Agree
g) Agree
h) Undecided
i) Disagree
j) Strongly Disagree

6. The lecture on HPV and oral cancer affected my professional behaviors.

f) Strongly Agree

g) Agree

h) Undecided

i) Disagree

j) Strongly Disagree

7. Since the course, I have encouraged more of my patients with a high lifetime number of sexual partners to have oral cancer screenings.

f) Strongly Agree

g) Agree

h) Undecided

i) Disagree

j) Strongly Disagree

8. In the past 3 months I have taken every opportunity to speak with patients about the potential of HPV causing oral cancer.

f) Strongly Agree

g) Agree

h) Undecided

i) Disagree

j) Strongly Disagree

9. In the future I will engage and educate the public about the link between HPV and oral cancer.
a) Strongly Agree
b) Agree
c) Undecided
d) Disagree
e) Strongly Disagree

10. Would you like more information concerning oral cancer and HPV?
a) Yes
b) No 


\section{Appendix B: Statistical Tables}

\section{Table 1: Demographics}

Age: $40 \%$ 51-60, 32\% 41-50, 13\% 31-40, 11\% 61+, 4\% 21-30

Gender: $92 \%$ female, $4 \%$ no data, $3 \%$ prefer not to say, $1 \%$ male

Professional Concentration: 72\% Nursing, 13\% Administration, 9\% Dental, 3\% Education, $3 \%$ No data

Highest Level of Education: 47\% Associate, 39\% Bachelor, 9\% Master, 4\% No data, 1\% Doctorate

\begin{tabular}{|c|c|}
\hline Question & Most common response (descending order) \\
\hline $\begin{array}{l}\text { 1: What is the age range of the majority of } \\
\text { patients that you see? }\end{array}$ & $\begin{array}{l}20-30(42 \%), \text { Under } 20(28 \%), \text { No data } \\
(19 \%), 30-40(8 \%), 40-50(1 \%), 60+(1 \%)\end{array}$ \\
\hline $\begin{array}{l}\text { 2: I talk with patients about HPV what } \\
\text { percentage of the time? }\end{array}$ & $\begin{array}{l}<10 \%(25 \%), 10-30 \%(21 \%), 30-50 \%(19 \%), \\
70-100 \%(17 \%) 50-70 \%(11 \%), \text { No data }(7 \%)\end{array}$ \\
\hline $\begin{array}{l}\text { 3: What percentage of the patients that you } \\
\text { see do you recommend the HPV vaccines to? }\end{array}$ & $\begin{array}{l}90-100 \%(21 \%),<10 \%(20 \%), 30-50 \% \\
(17 \%), 50-70 \%(17 \%), 10-30 \%(16 \%), \text { No } \\
\text { data }(8 \%)\end{array}$ \\
\hline \multicolumn{2}{|c|}{ Nursing only questions: } \\
\hline $\begin{array}{l}\text { 4: What is the age range of the majority of } \\
\text { HPV positive patients that you see? }\end{array}$ & $\begin{array}{l}20-30(47 \%), \text { No data }(26 \%), \text { Under } 20 \\
(15 \%), 30-40(4 \%), 50-60(4 \%), \text { N/A }(3 \%), \\
\text { Unknown }(1 \%)\end{array}$ \\
\hline $\begin{array}{l}\text { 5: What percentage of the patients that you } \\
\text { see have been diagnosed with HPV? }\end{array}$ & $\begin{array}{l}10-30 \%(27 \%), \text { No data }(24 \%), 30-50 \% \\
(23 \%), \text { Unknown }(15 \%), 50-70 \%(7 \%), \text { N/A } \\
(4 \%), 70-100 \%(1 \%)\end{array}$ \\
\hline $\begin{array}{l}\text { 6: What percentage of the patients that you } \\
\text { see have received the HPV vaccine? }\end{array}$ & $\begin{array}{l}10-30 \%(31 \%), \text { No data }(26 \%), 30-50 \% \\
(20 \%),<10 \%(12 \%), 50-70 \%(5 \%), \text { Unknown } \\
(5 \%), 70-100 \%(0 \%)\end{array}$ \\
\hline
\end{tabular}




\begin{tabular}{|c|c|c|c|}
\hline \multirow{2}{*}{\multicolumn{4}{|c|}{$\begin{array}{l}\text { Table 2: Chi square tests for independence between Nurses and answer choices } \\
\text { Question 1: HPV can cause the following: }\end{array}$}} \\
\hline & & & \\
\hline & Pre & Post & Follow-up \\
\hline Chi Square Values & 0.1259 & 0.5250 & 6.4848 \\
\hline P- Values & 0.7076 & 0.4342 & 0.0269 \\
\hline Phi coefficient & 0.0437 & 0.0913 & $\mathbf{0 . 3 1 8 3}$ \\
\hline \multicolumn{4}{|c|}{ Question 2: Oral cancer caused by HPV can be detected in the following ways: } \\
\hline & Pre & Post & Follow-up \\
\hline Chi Square Values & 4.5129 & 0.6409 & 0.2717 \\
\hline P- Values & 0.0480 & 0.7157 & 1.0000 \\
\hline Phi coefficient & $\mathbf{0 . 2 6 1 5}$ & -0.1009 & 0.0652 \\
\hline \multicolumn{4}{|c|}{$\begin{array}{l}\text { Question 3: According to D'Souza what is considered a high lifetime number of oral-sex } \\
\text { partners? }\end{array}$} \\
\hline & Pre & Post & Follow-up \\
\hline Chi Square Values & 0.0252 & 2.0724 & 6.3242 \\
\hline P- Values & 1.0000 & 0.3212 & 0.0178 \\
\hline Phi coefficient & -0.0196 & -0.1814 & $\begin{array}{r}0.3143 \\
\end{array}$ \\
\hline \multicolumn{4}{|c|}{ Question 4: I am knowledgeable about the potential for HPV to cause oral cancers. } \\
\hline & Pre & Post & Follow-up \\
\hline Chi Square Values & 1.8132 & 0.7810 & 5.3321 \\
\hline P- Values & 0.2271 & 0.4167 & 0.0542 \\
\hline Phi coefficient & 0.1657 & 0.1126 & \begin{tabular}{|c|}
0.2886 \\
\end{tabular} \\
\hline \multicolumn{4}{|c|}{$\begin{array}{c}\text { Question 5: In the past } 3 \text { months I have taken every opportunity to speak with patients about the } \\
\text { potential of HPV causing oral cancer. }\end{array}$} \\
\hline & Pre & Post & Follow-up \\
\hline Chi Square Values & 0.6799 & 0.8765 & 14.5121 \\
\hline P- Values & 0.4096 & 0.3492 & 0.0001 \\
\hline Phi coefficient & 0.1015 & 0.1180 & 0.4762 \\
\hline
\end{tabular}




\begin{tabular}{|c|c|c|}
\hline \multicolumn{3}{|c|}{ Table 3: Chi square Results for Attitude Questions } \\
\hline \multicolumn{3}{|c|}{$\begin{array}{l}\text { Question 1: The lecture on HPV and oral cancer will affect my personal behaviors. } \\
\text { Strongly agree and agree }=1 \quad \text { All others }=0\end{array}$} \\
\hline & Post & Follow-up \\
\hline Chi Square Values & 0.0012 & 3.1385 \\
\hline p- Values & 0.9726 & 0.1004 \\
\hline Phi coefficient & -0.0043 & 0.02214 \\
\hline \multicolumn{3}{|c|}{$\begin{array}{l}\text { Question 2: The lecture on HPV and oral cancer will affect my professional behaviors. } \\
\text { Strongly agree }=1 \quad \text { Agree }=0\end{array}$} \\
\hline & Post & Follow-up \\
\hline Chi Square Values & 3.6052 & 1.0559 \\
\hline p- Values & 0.0576 & 0.4786 \\
\hline Phi coefficient & 0.2373 & 0.1284 \\
\hline \multicolumn{3}{|c|}{$\begin{array}{l}\text { Question 3: In the future I will engage and educate the public about the link between HPV and } \\
\text { oral cancer to my patients. } \\
\text { Strongly agree }=1 \quad \text { Agree }=0\end{array}$} \\
\hline & Post & Follow-up \\
\hline Chi Square Values & 1.4427 & 4.1584 \\
\hline p- Values & 0.2297 & 0.0803 \\
\hline Phi coefficient & 0.1501 & 0.2549 \\
\hline \multicolumn{3}{|c|}{$\begin{array}{l}\text { Question 4: After this course, I will encourage more of my patients with a high lifetime number } \\
\text { of sexual partners to have oral cancer screenings. } \\
\text { Strongly agree }=1 \quad \text { Agree }=0\end{array}$} \\
\hline & Post & Follow-up \\
\hline Chi Square Values & 0.2748 & 2.0786 \\
\hline p- Values & 0.6001 & 0.1802 \\
\hline Phi coefficient & 0.0655 & 0.2619 \\
\hline
\end{tabular}




\begin{tabular}{|c|c|c|c|c|c|c|c|}
\hline \multicolumn{8}{|c|}{ Table 4: Logistic Regression Results of Nurses answer choices across all 3 surveys } \\
\hline \multicolumn{8}{|c|}{ Question 1: Circle all that apply; HPV can cause the following: } \\
\hline & Beta & $\begin{array}{c}\text { Standard } \\
\text { Error }\end{array}$ & $\begin{array}{l}\text { Chi sq } \\
\text { (Wald) }\end{array}$ & Sig/pvalue & $\begin{array}{l}\text { Odds } \\
\text { Ratio }\end{array}$ & CI Lower & $\begin{array}{c}\text { CI } \\
\text { Upper }\end{array}$ \\
\hline Intercept & 0.00208 & 0.9152 & 0.0000 & 0.9982 & & & \\
\hline Pre & 0.1434 & 0.6839 & 0.0440 & 0.8339 & 1.154 & 0.302 & 4.409 \\
\hline Post & 0.3634 & 0.7083 & 0.2632 & 0.6079 & 1.438 & 0.359 & 5.764 \\
\hline $\begin{array}{l}\text { Follow- } \\
\text { up }\end{array}$ & 0.8274 & 0.5365 & 2.3784 & 0.1230 & 2.287 & 0.799 & 6.547 \\
\hline \multicolumn{8}{|c|}{$\begin{array}{l}\text { Question 2: Circle all that apply; Oral cancer caused by HPV can be detected in the following } \\
\text { ways: }\end{array}$} \\
\hline & Beta & \begin{tabular}{c|c} 
Standard \\
Error
\end{tabular} & $\begin{array}{l}\text { Chi sq } \\
\text { (Wald) }\end{array}$ & Sig/pvalue & $\begin{array}{l}\text { Odds } \\
\text { Ratio }\end{array}$ & CI Lower & $\begin{array}{c}\text { CI } \\
\text { Upper }\end{array}$ \\
\hline Intercept & 1.1773 & 0.6682 & 3.1048 & 0.0781 & & & \\
\hline Pre & 0.9272 & 0.6366 & 2.1216 & 0.1452 & 2.528 & 0.726 & 8.802 \\
\hline Post & -0.7633 & 0.7087 & 1.1601 & 0.2814 & 0.466 & 0.116 & 1.869 \\
\hline $\begin{array}{l}\text { Follow- } \\
\text { up }\end{array}$ & 1.0841 & 1.1128 & 0.9491 & 0.3300 & 2.957 & 0.334 & 26.187 \\
\hline \multicolumn{8}{|c|}{$\begin{array}{l}\text { Question 3: According to D'Souza, what is considered a high lifetime number of oral-sex } \\
\text { partners? }\end{array}$} \\
\hline & Beta & $\begin{array}{c}\text { Standard } \\
\text { Error }\end{array}$ & $\begin{array}{l}\text { Chi sq } \\
\text { (Wald) }\end{array}$ & Sig/pvalue & $\begin{array}{l}\text { Odds } \\
\text { Ratio } \\
\end{array}$ & CI Lower & $\begin{array}{c}\text { CI } \\
\text { Upper }\end{array}$ \\
\hline Intercept & 0.9740 & 0.5494 & 3.1427 & 0.0763 & & & \\
\hline Pre & 0.0597 & 0.5782 & 0.0107 & 0.9177 & 1.062 & 0.342 & 3.297 \\
\hline $\begin{array}{l}\text { Follow- } \\
\text { up }\end{array}$ & -0.1195 & 0.5347 & 0.0500 & 0.8231 & 0.887 & 0.311 & 2.530 \\
\hline \multicolumn{8}{|c|}{ Question 4: I am knowledgeable about the potential of HPV to cause oral cancer. } \\
\hline & Beta & $\begin{array}{c}\text { Standard } \\
\text { Error }\end{array}$ & $\begin{array}{l}\text { Chi sq } \\
\text { (Wald) }\end{array}$ & Sig/pvalue & $\begin{array}{l}\text { Odds } \\
\text { Ratio }\end{array}$ & CI Lower & $\begin{array}{c}\text { CI } \\
\text { Upper }\end{array}$ \\
\hline Intercept & 0.7251 & 0.3971 & 3.3346 & 0.0678 & & & \\
\hline Pre & -0.0899 & 0.6649 & 0.0183 & 0.8924 & 0.914 & 0.248 & 3.364 \\
\hline Post & -0.3248 & 0.5590 & 0.3377 & 0.5612 & 0.723 & 0.242 & 2.161 \\
\hline $\begin{array}{l}\text { Follow- } \\
\text { up }\end{array}$ & 1.8316* & 0.7978* & $5.2701 *$ & $0.0217 *$ & $6.244 *$ & $1.307 *$ & $29.825 *$ \\
\hline \multicolumn{8}{|c|}{$\begin{array}{l}\text { Question 5: In the past } 3 \text { months I have taken every opportunity to speak with patients about } \\
\text { the potential of HPV causing oral cancer. }\end{array}$} \\
\hline & Beta & $\begin{array}{c}\text { Standard } \\
\text { Error }\end{array}$ & $\begin{array}{l}\text { Chi sq } \\
\text { (Wald) }\end{array}$ & p-value & $\begin{array}{l}\text { Odds } \\
\text { Ratio }\end{array}$ & CI Lower & $\begin{array}{c}\text { CI } \\
\text { Upper }\end{array}$ \\
\hline Intercept & 1.3185 & 0.8963 & 2.1640 & 0.1413 & & & \\
\hline Pre & -0.0795 & 0.5495 & 0.0209 & 0.8849 & 0.924 & 0.315 & 2.711 \\
\hline Post & -0.8042 & 0.8240 & 0.9524 & 0.3291 & 0.447 & 0.089 & 2.250 \\
\hline $\begin{array}{l}\text { Follow- } \\
\text { up }\end{array}$ & 0.5125 & 0.5773 & 0.7881 & 0.3747 & 1.669 & 0.539 & 5.175 \\
\hline
\end{tabular}




\begin{tabular}{|c|c|c|c|}
\hline \multicolumn{4}{|c|}{ Table 5: Frequency of Selecting Correct Answer } \\
\hline & Pre-Intervention & Post-Intervention & Follow-Up \\
\hline \multicolumn{4}{|c|}{ Question 1: HPV can cause the following: } \\
\hline $\begin{array}{l}\text { Percentage }(n) \text { change from } \\
\text { pre }\end{array}$ & $83 \%(n=62)$ & $86 \%(n=64)+2$ & $68 \%(\mathrm{n}=50)-12$ \\
\hline \multicolumn{4}{|c|}{ Question 2: Oral cancer caused by HPV can be detected in the following ways: } \\
\hline $\begin{array}{l}\text { Percentage }(n) \text { change from } \\
\text { pre }\end{array}$ & $32 \%(\mathrm{n}=24)$ & $78 \%(n=58)+34$ & $14 \%(\mathrm{n}=10)-\mathbf{1 2}$ \\
\hline \multicolumn{4}{|c|}{$\begin{array}{l}\text { Question 3: According to D'Souza, what is considered a high lifetime number of oral-sex } \\
\text { partners? }\end{array}$} \\
\hline $\begin{array}{l}\text { Percentage }(n) \text { change from } \\
\text { pre }\end{array}$ & $72 \%(n=54)$ & $92 \%(n=68)+\mathbf{1 4}$ & $61 \%(n=45)-9$ \\
\hline \multicolumn{4}{|c|}{ Attitude Questions } \\
\hline \multicolumn{4}{|c|}{ Question 4: I am knowledgeable about the potential of HPV to cause oral cancer. } \\
\hline $\begin{array}{l}\text { Percentage of Strongly } \\
\text { Agree and Agree (n) change } \\
\text { from pre }\end{array}$ & $84 \%(n=63)$ & $96 \%(n=71)+8$ & $72 \%(n=53)-\mathbf{1 0}$ \\
\hline \multicolumn{4}{|c|}{$\begin{array}{l}\text { Question 5: In the past } 3 \text { months I have taken every opportunity to speak with patients } \\
\text { about the potential of HPV causing oral cancer. }\end{array}$} \\
\hline $\begin{array}{l}\text { Percentage of Strongly } \\
\text { Agree and Agree (n) change } \\
\text { from pre }\end{array}$ & $44 \%(n=33)$ & N/A & $73 \%(\mathrm{n}=53)+\mathbf{2 0}$ \\
\hline
\end{tabular}

